\title{
Creating a Context for Girl of Color Ways of Knowing Through Feminist of Color Playwriting
}

\author{
Grace D. Player
}

\begin{abstract}
This article investigates how playwriting served three middle school Black girls within a larger practitioner research study seeking to better understand the literate practices of girls of color. It delves into the ways that playwriting provided the girls in an afterschool writing club opportunities to explore both their knowledge and ways of knowing, rooted in their cultural, gendered, and racialized experiences, and, in turn, share these with others, within an academic setting. It points to the necessity for creating writing pedagogies that celebrate experiential, cultural, emotional, and relational knowledge, using playwriting as an example.
\end{abstract}

\section{Background}

After school hours, in the library of an ethnically and linguistically diverse Catholic school in a large Northeastern city, eight girls of color gathered weekly after school to write, to read, to talk, to dance, to create. This writing club was designed specifically for them-to invite them to explore the writing and art of women of color writers, activists, artists, and intellectuals, and to provide an academic context in which they could tap into their own writerly, activist, artistic, intellectual girl of color selves with and alongside one another. They named this club "The Unnormal Sisterhood" and they shaped it into a place that centered and celebrated their knowledge and their ways of knowing.

On one spring day, the Unnormal Sisters sat in every part of the library, some by themselves, some in clusters. Throughout this writing period, they ebbed and flowed through various acts of writingsometimes typing, sometimes scribbling in their notebooks, sometimes conversing with their partners, sometimes listening to music as they sat thoughtfully in silence, sometimes reading aloud what they had already written, sometimes chatting about nothing related to their plays, as they allowed their minds to wander. I rotated through the room, checking in with them, reading what they' $\mathrm{d}$ written, conferring with them. Over the course of the year, the girls collectively dug into the topics that concerned them the most and were now working to write plays to bring to life their emotional, imaginative, and theoretical understandings of those issues. Diamond ${ }^{1}$ and Seraphina were huddled over the computer keyboardtaking turns typing and carefully choosing the words to best convey their ideas about the relationships to their teachers.

I settled into a chair next to them and watched them write for a while. Eventually, I asked why they were writing this particular story. Seraphina replied, "I want teachers to know what it would feel like if the students talked to them the way they talk to students." She elaborated, "They need to learn new ways to 
teach a child. It's not the 1990s anymore and you can't just scream at them." In this statement, she showed her understanding of her rights to dignity. These were understandings rooted in her own experiences with teachers and in the emotions associated with those experiences. Playwriting was a vehicle through which she and Diamond processed, expressed, and shared their knowledge and theories of oppression and change. This article investigates how playwriting operated for Black girls. It delves into the ways that playwriting provided the Unnormal Sisterhood with a pedagogy that opened space to explore their knowledge and ways of knowing, rooted in their cultural, gendered, and racialized experiences, and, in turn, share these with one another.

\section{Story of the Question}

Black girls find themselves located at the intersections of racism and sexism (Crenshaw, 1993). In schools, Black girls, in particular, are often subject to myriad physical and symbolic violences. They are disproportionately and harshly surveilled, disciplined, expelled, and criminalized in schools that too often prioritize discipline and control over education (African American Policy Forum \& Center for Intersectionality and Social Policy Studies, 2015). What's more, as a result of combined racist and monolithic narratives about Black girls and limited perceptions of what femininity should be, Black girls are often disciplined and commanded to be more "ladylike." They are punished for behaviors and attitudes that could, in fact, lead to educational success, for example, outspokenness, assertiveness, commitment, and a feeling of deservedness (Morris, 2016).

The impetus behind the creation of the Unnormal Sisterhood was an effort to reimagine what educational spaces could look like for girls of color in the face of these and other intersecting structural oppressions facing not only Black girls, but also Asian and Latina girls. This project took place at a K-8 Catholic school that served almost exclusively low-income and working-class Black, Asian, and Latinx students, but employed almost exclusively white teachers. The school too often abided by curriculum and disciplinary measures that were at best marginalizing, and, at worst, violent to the students. The project grew out of knowledge and curiosities born out of my own identity as an Asian-American woman of color educator and writer, my immersion in the community surrounding the girls' school, and my understandings of the intersecting oppressions that affect girls of color in this country (African American Policy Forum \& Center for Intersectionality and Social Policy Studies, 2015; Morris, 2016; Sealey-Ruiz, 2016). Using a feminist of color framework, the Unnormal Sisterhood was an attempt at building a writing and literacy curriculum for girls of color that attended to and celebrated their knowledge and ways of knowing, which are too often ignored, misunderstood, and fragmented through the white heteropatriarchal epistemologies that shape mainstream schooling. 


\section{Theoretical Framework: Feminist of Color Ways of Knowing and Writing}

This paper is an invitation to attune to the brilliances of Black girls - their sensemaking, critiques, theories, and proposals for change that arise from their experiences in this world, their cultural legacies, their emotional understandings, and their relationships to one another. Taking on a feminist of color framework that centers girl of color knowledge rejects a white heteropatriarchal lens and allows us to more accurately understand both the oppressions that girls of color face as well as the ways that they are brilliant, agentive, and passionate (Evans-Winters \& Esposito, 2010; Sealey-Ruiz, 2016).

Black girls are able to most accurately theorize the intersections of racism and sexism and suggest change because they, themselves, have lived life at these intersections (Collins, 2000; hooks, 2015; Mohanty, 2000; Moya, 2000). It stands to reason that Black girls, who have experienced racism and sexism-and possibly, if not likely, other categories such as homophobia, classism, and ableismare those most knowledgeable about how to challenge the matrix of domination (Collins, 2000) that upholds intersecting oppressions.

Importantly, there are not only types of knowledge, but also ways of knowing that contribute to the ability of women and girls of color to theorize and propose change to oppressive structures. As Anzladúa (1983) has philosophized, it is often in our bodies that we make sense of the world, that we feel and therefore understand both pleasure and oppression, freedom and constriction. Black feminists have attended to this idea as well. For instance, Fannie Barrier Williams names Black women's anxiety "as an emotion integral to race women's politics... rooted in an intrinsic bodily awareness about Black women's corporeal vulnerability" (as quoted by Cooper, 2017 p. 41). Emotions, and in particular, rage, can be put to important anti-racist and feminist causes when utilized with precision, a skill that women of color across time have had to develop (Cooper, 2017).

Girls of color are also privy to specific ways of knowing born of cultural and gendered knowledge. They are inheritors of legacies of struggle, conquest, and resistance, stories of which are passed down by and amongst women and girls of color (Delgado-Bernal, 2006). This knowledge transmission often occurs through caring relationships, as women of color enact care as a form of resistance to white heteropatriarchal structures (Collins, 2000). The knowledge transmitted and shared between and among girls and women of color is rooted in cultural practices of mutuality that leverage literacies that are relational, emotional, and embodied (Ghiso, 2016).

Too often, though, the understandings of girls of color are relegated out of academic spaces through narrow and hegemonic definitions of knowledge and theory. Their intellect, innovation, and creativity are obscured by controlling images that frame them as less capable, less brilliant, and less adept for schooling than their white and male peers (Collins, 2000). Emotional and experiential knowledge is placed at odds, rather than in cohesion, with conceptions of rationality (hooks, 1994; Jaggar, 1989). Further, because of the ways that women of color are simultaneously raced and gendered, their knowledge is often labeled as irrational, as outrage, as incomprehensible from a white masculine standpoint (Ahmed, 2012). Thus, in dominant academic spaces, theories of change rooted in woman of 
color knowledge are marginalized, perhaps at times purposefully, as white supremacist and masculinist ideologies persist.

I suggest a reimagining of academic spaces in order to center and celebrate the woman of color knowledge and ways of knowing. Playwriting and performance served as a platform for this work, as it provided space for girls to investigate their experiences, enact emotions, and build on knowledge born of woman of color cultures of resistance and caring.

\section{Playwriting and Performance to Access Feminist of Color Ways of Knowing}

Writing, as so many women of color feminists have discussed, can be a pathway toward processing emotional knowledge, claiming one's experience, and speaking back to negative stereotypes. Gloria Anzaldúa (1983) explained the impact of writing for her as a woman of color when, in response to the question of why she is compelled to write, she claimed:

Because I must keep the spirit of my revolt and myself alive. Because the world I create in the writing compensates for what the real world does not give me. By writing I put order in the world, give it a handle so I can grasp it. I write because life does not appease my appetites and hunger. I write to record what others erase when I speak, to rewrite the stories others have miswritten about me, about you. To become more intimate with myself and you. (pp. 168-169)

With these words, Anzaldúa explicates the importance of writing as both a rebellion and a means of survival in the face of oppression. She explains that writing is a route toward exploring experiences and tapping into emotions. What's more, she notes that writing is relational, that it facilitates the building of intimacy between women of color. This reflects what Mónica González Ybarra (forthcoming) names as qualities of girl of color literacies: "(1) em [bodied] and intergenerational, (2) disruptive, and (3) reflective and shifting."

In the Unnormal Sisterhood, playwriting became one genre through which the girls could employ their literacies. As Brazilian revolutionary theater director and writer, Augusto Boal (1979), has asserted, "theatre is a weapon of the oppressed" (as quoted by Fine, 2011, p. 145) and, further, it is rehearsal for the revolution. Jeanne-Marie Miller (1982) demonstrates this utility of playwriting by citing a history of Black women's playwriting as an expression of Black humanity, exploring Black experience from a Black point of view. Citing playwrights like Sonia Sanchez, Lorraine Hansberry, Ntozake Shange, and others, Miller demonstrates the way that Black women have used theater as affirmative, revolutionary, idea-laden, and fantasy driven.

Black women playwrights have told the Black woman's story-from slavery to freedom-from her point of view. The plays have focused on her tragedies; her struggles; her dreams for herself, her family, and her race. Their images of Black women are usually positive, and their female characters, for the most part, have great moral strength. (p. 289) 
She adds that Black women playwrights were not writing solely for themselves, but also for each other and for other oppressed people. Playwriting, then, is not only an act of self-preservation, but an act of coalition and care. Indeed, it holds potential to reflect the qualities of girl of color literacies.

\section{Literature Review}

Maisha Winn's (2011) ethnographic inquiry into the ways incarcerated and formerly incarcerated girls wrote and performed texts in a playwriting group demonstrates the power of playwriting girls of color. She found that playwriting allowed girls to explore and express their experiences, identities, and desires. It gave space for girls to inquire into the numerous structural inequities they faced and put words to their desires for their futures. Girls were able to fictionalize and perform some of their own experiences and therefore analyze their lives, their sense of deservingness, and hopes. Moreover, playwriting invited what Winn describes as an "ensemble" where teachers and students worked together to establish shared goals and connect over efforts to achieve those goals. Playwriting served as a mechanism for girls of color to utilize their power and resist oppressive narratives with and alongside one another.

In addition to writing, performance of places can give girls of color the opportunity to further explore their understandings by acting them out. Performances of their writing allows them to engage their embodied literacies, enacting emotions and drawing understanding from those enactments. Embodied literacies can open girls to criticality as they attune not only their mind, but their bodies to the world (Johnson \& Vasudevan, 2012). Further, acting out plays allows girls to enter one another's texts, thus becoming critically attuned to the experiences and calls for resistance of their sisters (Gallagher \& Ntelioglou, 2011). Playwriting can also illuminate youth perspectives on issues of inequity, challenging "common sense" understandings developed by adults of phenomenon that most directly affect youth, and in particular, youth of color (Conrad, 2005). Finally, as Lee and De Finney (2008) have investigated, performance of plays written by girls of color can help them to overcome a feeling of aloneness that results from their racialized experiences and to engage in conversations about those experiences with others. In all, playwriting and performance is a way for girls of color to engage in coalitional literacies that tap into their stories, emotions, and imaginings of change.

\section{Methodology}

The Unnormal Sisterhood developed during a yearlong practitioner inquiry project (Cochran-Smith \& Lytle, 2009) in partnership with eight Black and Asian middle school girls. The methodologies to study the Unnormal Sisterhood was rooted in humanizing (Paris \& Winn, 2014) and ethical community-based (Campano, Ghiso, \& Welch, 2016) methodologies. Building from ideas of culturally sustaining pedagogies (Paris \& Alim, 2017), the curriculum of the Unnormal Sisterhood sought to center the knowledge and theories of the girls and women of color involved as critically important to understanding the ways the intersections of gender and race were implicated in literacy pedagogy and the envisioning of literacy pedagogy (Evans-Winters \& Esposito, 2010; Sealey-Ruiz, 2016; Muhammad, 2018). 
My practitioner inquiry stance allowed me to not only understand patterns, but to also create conditions for growth and change. It allowed me to reflexively engage in data I collected across the course of the club, adjusting my own pedagogies to best serve the needs and desires of the girls in the club over time.

Influenced by Campano and colleagues (2016), I worked with the girls as collaborative knowledge producers, rejecting the colonial notion that, as a researcher, I was the sole holder of knowledge. It was through the establishment of sincere and sustained relationships with the girls that we were able to build trust from which coproduced girl of color knowledge emerged. The trusting relationships gave way to honest and open dialogic learning that would likely be unavailable through more traditional and distanced research methods (Kinloch \& San Pedro, 2014).

The data off of which my analysis grew came in the form of fieldnotes, transcribed semi-structured interviews and focus groups, and artifacts including girls' writing and art. I iteratively analyzed this data, filtered through the woman of color lens I employ, finding emerging thematic and in vivo codes to mark patterns and anomalies across the multiple sources of data. I also looked across my data sources, understanding that the multiple dimensions of context, texts, individuals, and relationships needed to be viewed as related and affecting one another. To grapple with this sense I was making, I wrote ongoing reflexive memos to crystalize meaning (Richardson \& St. Pierre, 2008) and help me to shape the course of the pedagogy to suit the needs and desires of the girls. To help ensure the centering of the girls' knowledge, I performed member checks, bringing back my initial analysis to the girls to confirm if my interpretations seemed accurate to them. These methods allowed me to understand their plays, their critiques, and their experiences with more depth and more attunement to their brilliances. Further, by using a feminist of color framework, I was able to filter understandings of their work through a lens that rejected potentially racist and sexist interpretations girls of color are too often subject to by dominant audiences. The following sections synthesize data gathered from the work of three Black girls in the group, tracing the ways they wrote, worked together and independently, performed, and reflected through the process.

\section{Emerging Themes}

The focus of this article is on two of the plays produced in the Unnormal Sisterhood, one written by a duo of girls, Seraphina and Diamond, and one written independently by Ciara. The plays were inspired by the work of Dr. Gerald Campano's (2007) students, who wrote critiques of their own schooling in the form of plays. After reading and discussing Dr. Campano's students' work, the girls discussed the ways that playwriting could be a method to take on their own critiques of schooling, taking a specifically girl of color perspective to elucidate how they experienced school.

Amongst the girls in the club, the issues of student-teacher relationships and sexual harassment emerged as most prevalent. In the following plays, these issues were explored collaboratively through writing and performance as girls shared their experiences with these issues, their empathy for others experiencing connected hardships, and their imagining of alternative possibilities for how these issues would unfold. 
I offer, here, their scripts, conversations about their scripts, documentation of their performances, and a feminist of color reading of these scripts. I am purposeful in reading these through the feminist of color lens in order to disrupt white hegemonic interpretations of Black girlhood that may fail to see the theories and understandings Black girls bring to literacy curriculum.

\section{Seraphina \& Diamond: "Teachers Getting Taught a Lesson"}

At the time of writing their play, Seraphina was a seventh grader and Diamond was a sixth grader. Both were Black girls. Both attended the same Catholic K-8 school. Seraphina was a cheerleader, a straight-A student, and later became 8th grade class president. She claimed a strong commitment to race and gender equity. Diamond was a talented poet and dancer who came to identify as a lesbian. She was an outspoken critic of police violence and racism. She was also a student who was in trouble often, got sent to the office frequently, and was eventually expelled from their school when she was in the 7th grade. They decided to partner in writing this play (see Figure 1) because they both were passionate about challenging the ways students were treated by teachers in schools. Though Seraphina was rarely a direct recipient of disciplinary measures, she frequently witnessed her classmates as targets of racist and sexist language. Diamond, on the other hand, was frequently a target of mistreatment at the hands of her teachers.

\begin{tabular}{|c|c|}
\hline Teachers getting taught a lesson & Scene 3 \\
\hline $\begin{array}{l}\text { *Mrs.Graceia *Xhocitli mom } \\
\text { *Diamond } \quad * \text { Mr. Langson } \\
\text { *Xhocitli }\end{array}$ & $\begin{array}{l}\text { Both Xhocitli and Diamond's parents are furious at the teacher's comments } \\
\text { about Xhocitli's homeland \{Peru\} }\end{array}$ \\
\hline Scene 1 & $\begin{array}{l}\text { Xhocitli mother: How dear you allow such mockery to go on in your } \\
\text { school. Isn't America supposed to be diverse and cherish one another's } \\
\text { cultures? Should you allow this? }\end{array}$ \\
\hline $\begin{array}{l}\text { *Students enter the classroom } \\
\text { Diamond: Were do I sit Mrs. Graceia }\end{array}$ & $\begin{array}{l}\text { Xhocitli: }\{\text { Que horrible, sin valor cerdo racist }\} \text { you horrible worthless } \\
\text { racist pig }\end{array}$ \\
\hline Mrs. Graceia: Right next to Xhocitli & Xhocitili mom: Ie encenderán $\{$ you will be fired\} \\
\hline $\begin{array}{l}\text { Xhocitil: Hi what is your name mine is Xhocitli I just come here from Peru sorry if } \\
\text { my English isn't the best. }\end{array}$ & $\begin{array}{l}\text { Mrs.Graceia: Vaya por delante que así perunan ningún trabajo que tiene } \\
\text { que de cruzar la frontera con el sida que tenga azada *screaming and } \\
\text { taking the two girls with her }\end{array}$ \\
\hline $\begin{array}{l}\text { Diamond: Its fine } \\
\text { Diamond: Why did you come here? }\end{array}$ & $\begin{array}{l}\text { Scene } 4 \\
\text { *Later that week }\end{array}$ \\
\hline $\begin{array}{l}\text { Xhocitli : Well their was gangs rivalries in our hometown of Lima so we left and } \\
\text { when to American for a better life. We also heard that the United States was one of } \\
\text { the most diverse places on the planet }\end{array}$ & $\begin{array}{l}\text { Mrs.Graceia: Because I was in a meeting with two of my students*eye } \\
\text { balling Diamond and Xhocitli* I am now not allow to talk about racial } \\
\text { things because are stundents our llorones (crybabies)... }\end{array}$ \\
\hline $\begin{array}{l}\text { Scene } 2 \\
\text { *A few months of school are in }\end{array}$ & $\begin{array}{l}\text { Xhocitli: Stop it right there you no right to talk about me or my home land } \\
\text { I try my best to keep up even thought I just came here heritage or put me } \\
\text { down for being me or disrespect my virtues you should be ashamed. }\end{array}$ \\
\hline $\begin{array}{l}\text { Mrs. Graceia: Kids we are learning about South America I am giving } 3 \text { weeks to } \\
\text { come up with a presentation and A dish from the country } \\
\text { Xhocitli: Yes (excited) can we do Peru? } \\
\text { Mrs. Graceia : OK (face looks confuse) }\end{array}$ & $\begin{array}{l}\text { Diamond: Right! You shouldn't just judge because where their from its } \\
\text { crazy. Also, if you want to talk about someone and where their from you } \\
\text { have to talk about everyone in the world and you because we all are from } \\
\text { specific country's or states and you need to realize how everyone is unique }\end{array}$ \\
\hline Diamond : What's wrong Teacher? & $\begin{array}{l}\text { Mrs.Graceia: Ir a morir a los estudiantes yo (go die you dumb students I } \\
\text { quit) }\end{array}$ \\
\hline $\begin{array}{l}\text { Mrs. Graceia: Ugh, Out of all the places why Peru? Because if you have a problem } \\
\text { you can address me with Mr. Langston } \\
\text { Xhocitli and Diamond: We will *angry * walking out of the class }\end{array}$ & $\begin{array}{l}\text { Seraphina| Yellow, My name is Seraphina I'm a } 13 \text { year old from } \\
\text { Philadelphia I wrote this to show that how you treat students. And isn't the } \\
\text { best because say if I called you a inmate how would you like it. I believe by } \\
\text { doing that degrades you as a person. I also don't like that when you get } \\
\text { mad or have a bad day you take it out on us and that's not cool. }\end{array}$ \\
\hline
\end{tabular}

Fig. 1: Seraphina and Diamond's Script $t^{2,3,4}$ 


\section{Employing Experiences to Critique the Mistreatment of Students}

To better understand their motivations and process in creating the play, I asked Seraphina what inspired them to write this play. She responded:

Me and Diamond didn't like how the teachers were treating us students. Like she would say how Ms. X would flick papers at her, call her names, scream at her, lie on her, so I just, influenced it, like how Ms. X would treat us in the beginning and put it in here, the play.

Here, Seraphina is showing the direct ways that their lived experiences shaped their motivation to address teacher treatment of students in their school. Seraphina and Diamond claimed that they wanted their teachers to better understand the ways that their language affected students.

Throughout their play, Seraphina and Diamond reflect their experiences through the violent language the teacher enacts. Seraphina and Diamond put on display racist and vitriolic behavior that reflects their own experiences. In the play, the girls write the teacher as someone who derides one of the students' home country of Peru, calls the students "crybabies," and who tells them to "go die." The teacher derides students' cultures, mocks their emotions, and incites violence. These are fictionalizations of very real experiences and pain, for as Seraphina frequently brought up across the course of the club, teachers' language made her feel "less than human."

In the closing soliloquy, Seraphina wrote:

I wrote this to show that how you treat students. And isn't the best because say if I called you a inmate how would you like it. I believe by doing that degrades you as a person. I also don't like that when you get mad or have a bad day you take it out on us and that's not cool.

Here, she specifically cites the use of the word "inmates," language she often reported as being used by her classroom teachers. According to Seraphina and Diamond's testimonies across the course of the club, teachers had called them inmates, animals, and things (as opposed to humans) and yelled at and ostracized them frequently.

Their play, then, is a reflection and analysis of their real-life experience. They engage storytelling and a subsequent soliloquy to employ an experience-based critique and narration that reflects the increasing criminalization of Black girls in schools across the nation (Morris, 2016). This critique of teacher behavior builds off of their emotional knowledge that results from their experiences with racism and sexism in the classroom. They offer a feminist of color critique that points to the dehumanizing pedagogies their teachers employ, and imagine and call for change.

\section{Enacting Coalitional Resistance Through Playwriting}

Playwriting allowed Diamond and Seraphina to inquire into and enact coalition amongst girls of color. One way in which they reflected their coalitional ideologies was by choosing to write one of their main characters as Latina, although neither of them claimed any Latina roots. When I asked the girls about this choice, they claimed it was because they had read about another Latina student in the plays we read by 
Dr. Campano's students and because Seraphina had read about a student who shared her character's name in her mother's teacher education materials. The girls synthesized a variety of experiences and texts to create a fictionalized account of teacher treatment of students that simultaneously replicated their own experiences while expressing empathy for girls with different ethnic identities, but who they understood likely also experienced racism. This follows in the tradition of women of color activists enacting care for all marginalized people with the understanding that "nobody's free until everybody's free" (Hamer, 2011, p. 136).

Diamond and Seraphina not only enact care themselves, but they also chose to story caring relationships amongst their characters. From the start of the play, the two girls portrayed, Diamond and Xhocitli, engage in conversations about their subjective realities-Diamond inquires into why Xhocitli has immigrated to the United States from Peru, showing a level of concern and curiosity that reflects care (Valenzuela, 1999). This relational care is not shown in Diamond and Seraphina's characterization of the teacher. The primary way that the fictionalized teacher attempts to engage with culture is through a research report and the preparation of an ethnic dish, objectives that seem rather removed from the relational work of understanding minoritized students' experiences and cultural knowledge. Diamond and Seraphina script the teacher's approach to multicultural education in a way that is at best, misguided, and, at worst, racist (Nieto, 1999; Paris \& Alim, 2017). They seem to intuit the carelessness of this kind of multicultural education, a topic taken up by many scholars engaging the concept of culturally sustaining pedagogies (Paris \& Alim, 2017). What's more, Diamond and Seraphina demonstrate an alternative by storying their girl of color characters as engaging care and curiosity for one another. The girl characters show support for one another, understanding that Xhochitli's cultural roots are part of her and worthy of celebration and potentially important content for the students' critical learning. In this way, they not only engage critique of Eurocentric notions of multicultural education, but they, further, suggest an alternative.

\section{Performance as a Route Toward Engaging Embodied Critique}

Performance also played an important role in creating pathways for Seraphina and Diamond to tap into their emotional knowledge. The emotions they named were not just expressed in words, but also in their physical enactments. This gave them the opportunity to play out their anger, stomping and throwing items on the floor as they acted out the scenes. Performance allowed them to tap into their embodied knowledge and physically project their emotional knowledge in ways that were too often punished in their classrooms, a phenomenon addressed by Diamond over time as she reported the multiple ways she was disciplined for moving, speaking, and interacting with others during class.

Through performance, though, not only were they connecting with their emotional knowledge, but they were using it to transmit knowledge to other girls as they shared their plays with the other Unnormal Sisters. As Cooper (2017) has discussed, there is power in women (and in this case, girls) of color taking their rage and directing it with precision and purpose. For Seraphina and Diamond, playwriting offered

a productive outlet for the intellectual work of using emotion as a foundation for critiques of injustice. They demonstrate, as Fahima Ife (2017) has explored, the critical value of attuning to Black girls' 
embodied critique. Through a woman of color theoretical viewpoint, we can reject the misreadings of Black girls' bodies, and instead understand that their bodily reactions are wisely pointing out acts of violence directed at them.

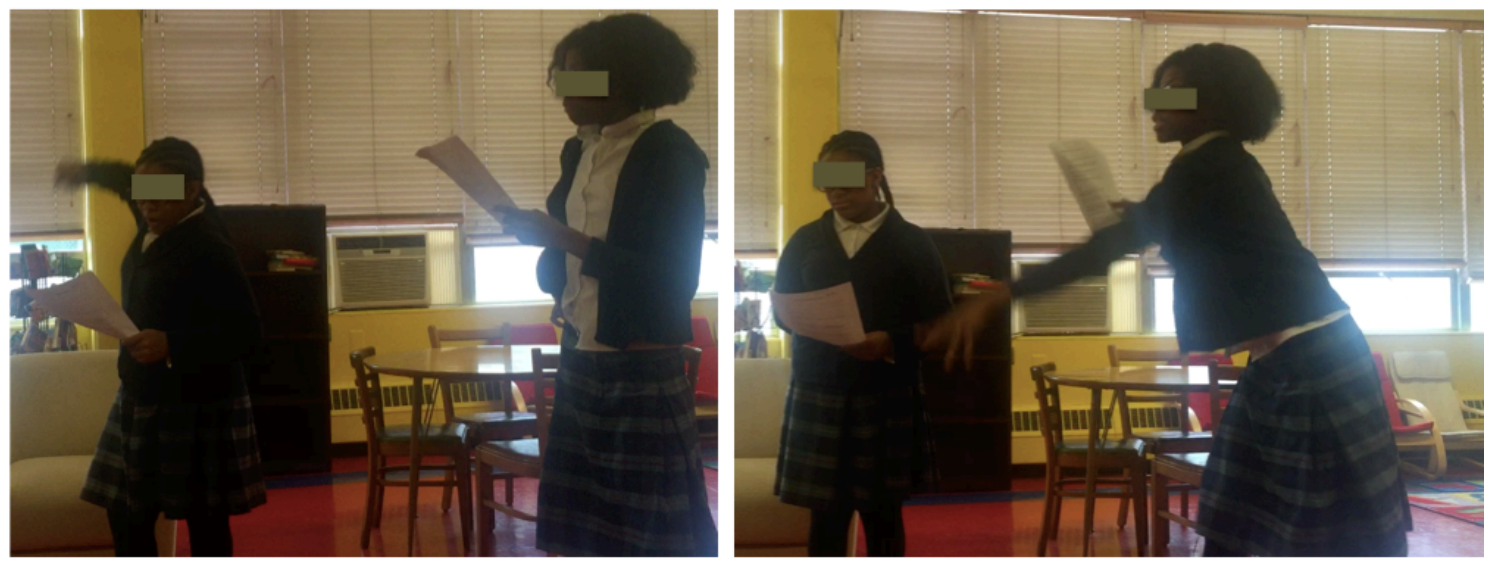

Fig. 2: Stills from a video of Diamond and Seraphina acting out their play.

This play gave the girls an opportunity to rewrite the world, imagining it as a place where they had more power to express their anger and their care for one another. Diamond and Seraphina reimagined school to be a place where they had agency to speak back to their teachers without major consequence, besides some escalating language from the teacher. In fact, in the end of the play, the teacher even quits her job, potentially freeing the girls from her wrath. The teacher's exit from the profession was, further, inspired by the coalitional work that the girls did. This revision of reality offered insight into and critique of the ways they, as girls of color, felt so often hurt and dismissed by teachers as well as the hope they see in their own caring relationships. By engaging the multiple girl of color literacies afforded by playwriting and performance, the girls enacted resistance, critique, and suggestions for change.

\section{Ciara: "Does She Know That Is Sexual Harassment?"}

Ciara, a sixth grader, identified as Black and female. She was a devoted music fan who saw Beyoncé and Nicki Minaj amongst her idols. When Beyoncé's 2016 album Lemonade came out, she was beyond ecstatic and spent many hours poring over the lyrics and visuals, making deep and concerted efforts to make sense of what she was hearing, reading, and seeing in Beyoncé's masterpiece. She, like Beyoncé, used her art, and in this case, her playwriting, both to analyze her relationship to her peers as well as to understand how structures of inequity shape those relationships. Her writing served as a vehicle to explore her experiences and relationships and, in turn, begin to make sense of structural sexism and analyze her own sometimes complicity in those structures. 


\begin{tabular}{|ll|}
\hline Daquan: Ayo Brianca. Bring that butt over here boi. & (Daquan walks into the room and talk to Ali.) \\
Stephanie: NO! & Daquan: Go slap Brianca's butt. \\
Daquan: Can you please come over here. & Ali: Why don't you go do it. \\
(Stephanie walks to Daquan) & Daquan: I can't. \\
Stephanie: Yes Daquan. & Ali: Ok \\
(Daquan slaps Steph butt) & (Ali smacks Brianca's butt.) \\
Stephanie: Stop touching me! & Brianca: Stop! (and giggles away) \\
Brianca: Stop touching people butts. & Steph: Tell Ms. Sherry. \\
Daquan: Nobody asked you, Stephanie. You know u like it. & Brianca: No. \\
Ali: Brianca you know you want ur butt slaped & Ali: She not going to tell because she like it. \\
Steph: I don't like it. & Brianca: I'm not telling because Im not a rat. \\
$\begin{array}{l}\text { Daquan: Stop lying. } \\
\text { Steph: Ms. Sherry. Daquan touched my butt! }\end{array}$ & (Steph talks to the crowd) \\
Ms Sherry: Daquan let me talk to you in the hallway. & Does she know that is sexual harassment? Does she like it? \\
(Daquan goes into the hallway to talk to Ms. Sherry) & Maybe she is a little slut. Wait. That's my friend I should \\
Ms Sherry: Why would you touch her butt? & have never said that. But wait do boys know that its not \\
Daquan: I was just playing & right. I shouldn't be blaming this on my friend. I should be \\
Ms. Sherry: Don't touch her again. & blaming it on the boys. Just because you like someone \\
Daquan: Ok. & doesn't mean you do something disrespectful. \\
\hline
\end{tabular}

Fig. 3: Ciara's script.

Ciara's play explored the ways that girls are labeled sexually promiscuous while the perpetrators of sexual harassment generally go unscathed. Further, she notes that those who are in positions of power-in this case, teachers-fail to protect girls of color in the face of harassment (see Figure 3). The content of the play reflected conversations the girls of the Unnormal Sisterhood had over time about the ways sexism affected the girls' lives. In the play, two girls interact with boys at their school who end up grabbing the girls' behinds. While the narrator protests, her friend simply lets it happen.

\section{Girl of Color Language at the Core of Critique}

During the scene, Ciara uses the language of her everyday life, not attempting to mold what is happening into school-sanctioned language. Thus, she captures something that feels very real, very of her life, that could not be illustrated within the constraints of what is too often seen in schools as the prized academic genre for middle schoolers: the five-paragraph essay. She is not constrained, either, but sentences and structures would fail to reflect her everyday experience. Playwriting allowed her to break convention, and instead, use the exact words she needed to story her experiences. As poet June Jordan (1988) points out, Black English has specific utility in communicating points, and often points about injustice. Jordan claims Black English is useful in insisting on one's existence, centralizing voice, and delivering messages with clarity. Indeed, these seem to be qualities of Ciara's play, as an oral reading conveys the very realness of Ciara's experiences, the very clear voices of her interlocutors.

Daquan: Ayo Brianca. Bring that butt over here boi.

Stephanie: NO!

Daquan: Can you please come over here.

(Stephanie walks to Daquan)

Stephanie: Yes Daquan.

(Daquan slaps Steph butt) 
Stephanie: Stop touching me!

Brianca: Stop touching people butts.

Daquan: Nobody asked you, Stephanie. You know u like it.

Ali: Brianca you know you want ur butt slaped

The use of her language, the repeated cries for it to stop, her capitalized "NO!" put us in a position to hear the pain of feeling underprotected in the face of sexual harassment in school. She draws from her multiple vocabularies and grammars, including "Black English," but also, taking on a more formalized tone when she addresses the audience in soliloquy. She picks up, skillfully, the ways that the boy characters employ sexist discourse; she shows the ineffectuality and curtness of her teachers' discourse; she employs a contemplative and explanatory tone to engage with the audience. Playwriting allowed her to take on multiple voices and skillfully utilize them to story and critique her experiences with sexual harassment.

\section{Playwriting to Move Toward Liberatory Ideologies}

Ciara also used playwriting to demonstrate the ways that she has transformed, painting an image of how ideologies shift as one pursues a justice orientation. In her soliloquy she writes:

Does she know that is sexual harassment? Does she like it? Maybe she is a little slut. That's my friend, I should have never said that. But wait, do boys know that it's not right? I shouldn't be blaming this on my friend. I should be blaming it on the boys.

Initially, she labels her friend being sexually promiscuous, and further denigrates her by using the sexist term "slut." But she pauses and shifts, realizing that this is her friend-her sister-another girl who has lived through the same sort of incidents as she has herself. In part, her theorization of sexual harassment is born out of her relationships to her sister. Motivated by care, she changes the course of her questioning.

At this point, she shifts to the question, "Do boys know that it's not right?" With this question she understands that her friend should not be punished for choosing not to speak up, as silence in these situations can often be a protective measure. She narrates her realization that she should be blaming the boys who are doing the criminal act, who are perpetuating sexist behavior, not being victimized by it, as her friend is. She elucidates the core of rape culture- that it is insidious and often unrecognized, and that, as a society, we are not teaching our boys to treat women and girls with love and dignity. Ciara shows the ways that enacting sisterly care can help girls shift away from blaming each other and shaming each other and toward holding boys accountable for their behavior and perceptions of women.

Playwriting served as a pathway toward taking control over a situation by providing Ciara with an opportunity to analyze sexism through the process of writing and the subsequent performance of her narrative. In this case, Ciara used it as a way to understand how she might redirect her negative perceptions away from other girls, girls who perhaps act in the world differently than herself, reserving and even reevaluating her judgments in order to be a better ally to them against various manifestations of sexist ideologies, some of which she experiences herself, and some of which she does not. 
In all, playwriting offered an opportunity for her to analyze her own experiences with sexual harassment and to begin to theorize an antisexist view rooted in her life and relationships.

\section{Conclusion}

Playwriting provided a space for girls of color in the Unnormal Sisterhood to explore and share experience-based knowledge, hopes and visions of change, theoretical understandings of sexism and racism, coalitional practices, and empathy. The girls' work offers images into what writing curriculum could look like if their knowledge and ways of knowing were centered in classrooms and literacy pedagogies. Specifically, playwriting served as culturally sustaining pedagogy (Paris \& Alim, 2017), which gave room for the girls to not only build off of their experiential and cultural knowledge, but to also critique various aspects of their worlds. Through their plays, they drew from linguistic, experiential, embodied, and relational knowledge to create sophisticated and nuanced critiques and understandings of their worlds. This openness to creating contexts that center and celebrate girls of color represents an important shift in what literacy pedagogy could be.

Girls and women of color will always make spaces for themselves. They will always engage in pedagogies that refuse the racist and sexist structures that can warp school-sponsored pedagogies into violent and destructive tools of oppression (Ohito, 2016). They have proven this over and over throughout history as they've developed formal and informal advocacy groups, art and writing collectives, and spaces of healing. It's time, though, that all educators learn from them to co-create spaces that interrupt white hegemonic structures of schools that allow them to thrive, not just because they've fought tooth and nail to do so, but because educators have attuned themselves to the fact that girls deserve these spaces as much as any other student, and because they understand girls of color are the bringers of change who they need to partner with, listen to, and learn from as we fight intersecting oppressions.

\section{Notes}

1. All names are pseudonyms chosen by the girls themselves to simultaneously conceal their identities while also giving them choice in the way they were represented.

2. When asked why she chose to name the teacher [my first name plus the letters ia], Seraphina responded that "cuz I was thinking about you, but I was like, no you are too nice for all of that, and I just put an ia." I want to point this out, not completely out of vanity's sake, but because I think it is genuinely important. This idea of her contrast between my pedagogy and the pedagogies she critiques came up for her often and she frequently compared her relationships and learning between her classroom spaces and the space of the unnormal sisterhood.

3. Girls used Google Translate to write Spanish-language text.

4. Xhocitli was pronounced as and seems to be an approximation of the name Xochitl, a Nahuatl name meaning flower. 


\section{References}

African American Policy Forum \& Center for Intersectionality and Social Policy Studies. (2015). Black girls matter: Pushed out, overpoliced and underprotected. New York, NY:

Kimberlé Williams Crenshaw.

Ahmed, S. (2012). On being included: Racism and diversity in institutional life. Durham, NC: Duke University Press.

Anzaldúa, G. (1983). Speaking in tongues: A letter to 3rd world women writers. In C. Moraga \& G. Anzaldúa (Eds.), This bridge called my back: Writings of radical women of color (pp. 165-174). New York, NY: Kitchen Table: Woman of Color Press.

Campano, G. (2007). Immigrant students and literacies: Reading, writing, and remembering. New York, NY: Teachers College Press.

Campano, G., Ghiso, M. P., \& Welch, B. J. (2016). Partnering with immigrant communities: Action through literacy. New York, NY: Teachers College Press.

Cochran-Smith, M., \& Lytle, S.L. (2009). Inquiry as stance: Practitioner research for the next generation. New York, NY: Teachers College Press.

Collins, P.H. (2000). Black feminist thought: Knowledge, consciousness, and the politics of empowerment. New York, NY: Routledge.

Conrad, D. (2005). Rethinking 'at-risk' in drama education: beyond prescribed roles. Research in Drama Education, 10(1), 27-41.

Cooper, B. C. (2017). Beyond respectability: The intellectual thought of race women. Urbana, IL: University of Illinois Press.

Crenshaw, K. (1993). Demarginalize the intersections of race and sex: A Black feminist critique of antidiscrimination doctrine, feminist theory and antiracist politics. In D.K. Weisberg (Ed.), Feminist legal theory: Foundations (pp. 383-395). Philadelphia, PA: Temple University Press.

Delgado-Bernal, D. (2006). Learning and living pedagogies of the home: The Meztiza consciousness of Chicana students. In D. Delgado Bernal, C. A. Elenes, F.E. Godinez, \& S. Villenas (Eds.), Chicana/Latina education in everyday life: Feminista perspectives on pedagogy and epistemology (pp. 113-132). Albany, NY: State University of New York Press.

Evans-Winters, V., \& Esposito, J. (2010). Other people's daughters: Critical race feminism and Black girls' education. Educational Foundations, 24(1), 11-24.

Fine, M. (2011). Talk-back/talk-with: How does one applaud in text? In M. Winn (Au.), Girl time. New York, NY: Teachers College Press.

Gallagher, K., \& Ntelioglou, B. Y. (2011). Which new literacies? Dialogue and performance in youth writing. Journal of Adolescent \& Adult Literacy, 54(5).

Ghiso, M.P. (2016). The laundromat as the transnational local: Young children's literacies of interdependence. Teachers College Record, 118, 1-46.

Goldberg, N. (1986). Writing down the bones. Boston, MA: Shambhala. 
González Ybarra, M. (forthcoming). "We have a strong way of thinking... and it shows through our words": Exploring the Mujerista literacies of Chicana/Latina youth.

Hamer, F. L. (2011). Nobody's free until everybody's free. In M. P. Woods \& D. W. Houck (Eds.), The speeches of Fanny Lou Hamer (pp.134-139). Jackson, MS: University of Mississippi Press.

hooks, b. (1994). Teaching to transgress: Education as the practice of freedom. New York, NY: Routledge.

hooks, b. (2015). Feminist theory: From margin to center. New York, NY: Routledge.

Ife, F., (2017). Perhaps a Black girl rolls her eyes to shift calcified pain throughout her body. Bank Street Occasional Paper Series 38.

Jaggar, A. M. (1989). Love and knowledge: Emotion in feminist epistemology. An Interdisciplinary Journal of Philosophy, 32(2), 151-176.

Johnson, E., \& Vasudevan, L. (2012). Seeing and hearing students' lived and embodied critical literacy practices. Theory Into Practice, 51(1), 34-41.

Jordan, J. (1988). Nobody mean more to me than you and the future life of Willie Jordan. Harvard Educational Review, 58(3), 363-374.

Kinloch, V., \& San Pedro, T. (2014). The space between listening and storying: Foundations for projects in humanization. In D. Paris \& M.T. Winn (Eds.), Humanizing research: Decolonizing qualitative inquiry with youth and communities. Los Angeles, CA: Sage Publications.

Knowles, B. (2016). Lemonade [Visual album]. New York, NY: Parkwood Entertainment.

Lee, J., \& De Finney, S. (2008). Using popular theatre for engaging racialized minority girls in exploring questions of identity and belonging. Child \& Youth Services, 26(2), 95-118.

Miller, J.M.A. (1982). Black women playwright from Grimké to Shange: Selected synopses of their works. In G.T. Hull, P. B. Scott, \& B. Smith (Eds.), All the women are white, all the Blacks are men, but some of us are brave: Black women's studies. New York, NY: The Feminist Press.

Mohanty, S.P. (2000). The epistemic status of cultural identity: On beloved and the postcolonial condition. In M. Moya \& M. R. Hames-García (Eds.), Reclaiming identity: Realist theory and the predicament of postmodernism (pp. 29-66). Berkley, CA: University of California Press.

Morris, M. W. (2016). Pushout: The criminalization of Black girls in schools. New York, NY: The New Press.

Moya, P. (2000). Introduction: Reclaiming identity. In P. Moya \& M. R. Hames-García (Eds.), Reclaiming identity: Realist theory and the predicament of postmodernism (pp.1-23). Berkley, CA: University of California Press.

Muhammad, G. E. (2018). A plea for identity and criticality: Reframing literacy learning standards through a four-layered equity model. Journal of Adolescent \& Adult Literacy, 62(2), 137-142.

Nieto, S. (1999). The light in their eyes: Creating multicultural learning communities. New York, NY: Teachers College Press. 
Ohito, E. O. (2016). Refusing curriculum as a space of death for Black female subjects:

A Black feminist reparative reading of Jamaica Kincaid's "Girl." Curriculum Inquiry, 46(5), 436-454.

Paris, D., \& Alim, H. S. (2017). Culturally sustaining pedagogies: Teaching and learning for justice in a changing world. New York, NY: Teachers College Press.

Paris, D., \& Winn, M. (2014). Humanizing research: Decolonizing qualitative inquiry with youth and communities. Los Angeles, CA: Sage Publications.

Richardson, L., \& St. Pierre, E.A. (2008). Writing: A method of inquiry. In N.K. Denzin \& Y.S. Lincoln (Eds.), Collecting and interpreting qualitative materials (pp. 473-500). Thousand Oaks, CA: Sage Publications.

Sealey-Ruiz, Y. (2016). Why Black girls' literacies matter: New literacies for a new era. English Education, 48(4), 290-298.

Valenzuela, A. (1999). Subtractive schooling: U.S.-Mexican youth and the politics of caring. Albany, NY: State University of New York Press.

Winn, M. (2011). Girl time: Literacy, justice, and the school-to-prison pipeline. New York, NY:

Teachers College Press.

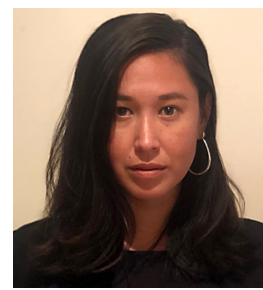

Grace D. Player is a Professor in the Curriculum and Instruction Program at the University of Connecticut Neag School of Education. She received her PhD from Penn GSE and is a former Cultivating New Voices Fellowship Recipient. Her research interests center girl of color literacies, coalitional literacies, and community literacies. Through her career, she has taken up feminist of color epistemologies in order to work with and alongside youth and communities of color to co-investigate the ways that they utilize a complex web of literacies to understand the world and advocate for themselves in the face of white supremacist heteropatriarchal structures. Her goals are to work towards the transformation of academic spaces to center and celebrate marginalized knowledge and ways of knowing. 